\title{
KUALIFIKASI, PERSEPSI, DAN KOMPETENSI GURU PAI SMP/MTS SE-KOTA PEKALONGAN DALAM PEMANFAATAN MEDIA PEMBELAJARAN BERBASIS TIK DI ERA GENERASI Z
}

\author{
Akhmad Zaeni*, Muchamad Fauyan, Ningsih Fadhilah \\ IAIN Pekalongan, akhmad.zaeni@iainpekalongan.ac.id
}

\begin{abstract}
This research is based on the finding that PAI SMP / MTs teachers in Pekalongan City in the generation $\mathrm{Z}$ era have not been optimal in utilizing learning media, especially ICT-based media, so that this research is intended to reveal the real conditions of qualifications, perceptions and competencies and causes of limited PAI teachers in develop or utilize ICT-based learning media. In addition, the process of planning, producing, utilizing and managing ICT-based learning media was also revealed by PAI teachers who had already practiced it. The results of this study were all PAI teachers who were the sample of the study had qualified as PAI SMP / MTs teachers. Their perception of the use of information and communication technology (ICT) based learning media is known to have a good category of tendencies / perceptions, while SMP / MTs teacher competencies in Pekalongan City in the use of Information and Communication technology (ICT) learning media in the category are quite good. Their competencies are influenced by internal factors and external factors so that there are things that support or hinder SMP / MTs PAI Teachers in Pekalongan City in utilizing ICT-based learning media in PAI learning. Therefore, it is expected that PAI teachers will be more motivated and have the willingness to improve their competence in utilizing ICT-based learning media that are tailored to teaching materials, student needs, environmental conditions and in accordance with the objectives to be achieved.
\end{abstract}

Keywords: Teacher competency, PAI teacher, Learning media, ICT

\begin{abstract}
Penelitian ini dilatarbekalangi adanya temuan bahwa guru PAI SMP/MTs Se-Kota Pekalongan di era generasi $\mathrm{Z}$ ini belum optimal dalam memanfaatkan media pembelajaran khususnya yang berbasis TIK sehingga penelitian ini dimaksudkan untuk mengungkap kondisi riil kualifikasi, persepsi, dan kompetensi serta penyebab keterbatasan guru PAI dalam mengembangkan atau memanfaatkan media pembelajaran berbasis TIK. Di samping itu, juga diungkap proses perencanaan, produksi, pemanfaatan, dan pengelolaan media pembelajaran berbasis TIK oleh guru PAI yang sudah pernah mempraktikkannya. Hasil penelitian ini adalah semua guru PAI yang menjadi sampel penelitian sudah memenuhi kualifikasi sebagai guru PAI SMP/MTs. Persepsi mereka terhadap pemanfaatan media pembelajaran berbasis teknologi informasi dan komunikasi (TIK) diketahui memiliki kategori kecenderungan/ persepsi baik, sedangkan kompetensi guru SMP/MTs se-Kota Pekalongan dalam pemanfaatan media pembelajaran berbasis teknologi Informasi dan Komunikasi (TIK) dalam kategori cukup baik. Kompetensi mereka itu dipengaruhi oleh faktor internal dan faktor eksternal sehingga ada hal-hal yang mendukung atau menghambat Guru PAI SMP/MTs Se-Kota Pekalongan dalam memanfaatkan media pembelajaran berbasis TIK dalam pembelajaran PAI. Oleh karena itu, diharapkan guru PAI lebih termotivasi lagi dan memiliki kemauan untuk meningkatkan kompetensinya dalam memanfaatkan media pembelajaran berbasis TIK yang disesuaikan dengan materi ajar, kebutuhan siswa, kondisi lingkungan dan sesuai dengan tujuan yang ingin dicapai.
\end{abstract}

Kata Kunci: Kompetensi guru, Guru PAI, Media pembelajaran, TIK

\section{PENDAHULUAN}

Dalam teori perubahan sosial ada perubahan yang disengaja dan tidak disengaja. Perubahan sosial yang disengaja salah satunya melalui proses pendidikan. Pendidikan dan perubahan sosial, keduanya saling bertautan satu dengan yang lain dan saling mempengaruhi. Sebagaimana Undang-Undang Nomor 20 tahun 2003 tentang Sistem Pendidikan Nasional pasal 1, pendidikan adalah usaha sadar dan terencana untuk 
mewujudkan suasana belajar dan proses pembelajaran agar peserta didik secara aktif mengembangkan potensi dirinya untuk memiliki kekuatan spiritual keagamaan, pengendalian diri, kepribadian, kecerdasan, akhlak mulia serta keterampilan yang diperlukan dirinya, masyarakat, bangsa dan negara. Menurut Haedari (2016), pendidikan merupakan sebuah elemen kebutuhan yang senantiasa mengalami perubahan. Perubahan dalam pendidikan menuntut rekayasa atau kesengajaan. Tapi bukan sembarang kesengajaan melainkan direncanakan.

Seiring perkembangan zaman, semakin pesat pula tingkat kualitas dan kebutuhan hidup manusia. Demikian halnya, dimensi pendidikan yang semakin kompleks, dan tentu saja hal itu membutuhkan sebuah desain atau teknologi pendidikan yang juga tepat dan sesuai dengan kondisinya. Oleh karena itu, berbagai teori, metode, dan desain pembelajaran, serta pengajaran dibuat dan diciptakan untuk mengapresiasi semakin beragamnya tingkat kebutuhan dan kerumitan permasalahan pendidikan.

Menjadi guru di era sekarang khususnya bagi generasi z memang membutuhkan perjuangan yang berat dan kemauan guru untuk meningkatkan keprofesionalannya. Hal ini juga berkaitan dengan peserta didik yang dihadapinya adalah peserta didik di zaman now pula. Yusmuliadi (2018) mengemukakan bahwa seorang guru tidak mampu menguasai kecanggihan teknologi di zaman now, bisa dipastikan guru tersebut akan tertinggal dalam pembelajaran dan dalam hal informasi dan peningkatan kompetensi yang dimilikinya, bahkan bisa saja terjadi seorang siswa akan mampu mengalahkan gurunya dalam hal penguasaan teknologi. Jika hal ini tidak diatasi maka guru akan mandeg kreativitasnya dan masyarakat akan semakin tidak percaya dengan kemampuan guru yang mendidik putra putrinya. Kenyataan itu, menurut Yusmuliadi terutama pada guru-guru senior yang memasuki usia 40 tahun keatas dengan banyaknya guru yang tidak menguasai teknologi. Banyak dari mereka ketika diminta untuk mengikuti kegiatan keprofesian seperti diklat, bimtek, workshop, dan lain sebagainya menolak untuk turut serta dengan alasan tidak bisa mengoperasikan komputer/laptop. Padahal saat ini di zaman milenial, semua pelatihan dilakukan dengan melibatkan teknologi di dalamnya, mulai dari proses pendaftaran, pengiriman berkas/laporan, pelaksanaannya yang serba online (daring), pretest dan post test yang online dan lain sebagainya. Sehingga selain kemampuan mengoperasikan komputer/laptop, guru juga dituntut untuk mampu menguasai teknologi aplikasi yang sedang masif menglobalisasi dunia. Dunia terasa menjadi lebih sempit dengan kemajuan teknologi, seperti: Facebook, Instagram, Tweeter, Email, google. Teknologi itu adalah contoh-contoh aplikasi yang akrab di telinga masyarakat.

Sejalan dengan hal di atas, diakui oleh Tobroni (2015) selaku Kepala Kankemenag Kota Pekalongan bahwa upaya-upaya peningkatan mutu layanan, daya saing dan tata kelola pendidikan agama dan keagamaan di Kota Pekalongan masih belum optimal, meskipun dari segi payung hukum dan kebijakan telah memadai. Salah satu persoalan pokoknya adalah rendahnya mutu tenaga pendidik baik dari sisi kualifikasi maupun kompetensinya. Ditinjau dari sisi kualifikasinya, menurut laporan Kakemenag Kota Pekalongan, masih banyak guru yang mengajar mismathc dan tidak linear. Bahkan, jika ditinjau dari kompetensinya, berdasarkan Uji Kompetensi Guru (UKG), capaian nilai guru profesional yang masih belum optimal, hanya 2 orang nilai profesional, rata rata layak, dan 2 orang pembinaan. Dari aspek ini pula patut diduga belum optimalnya pemanfaatan media pembelajaran khususnya yang berbasis TIK oleh guru tak terkecuali guru PAI.

Tambahan lagi, berdasarkan studi pendahuluan atau hasil survei yang dilakukan oleh M. Sugeng Sholehudin pada 50 guru PAI (peserta pelatihan media pembelajaran bagi guru SMP/MTs se-Kota Pekalongan) tanggal 12-13 Agustus 2015 di Gedung Diklat BKD kota Pekalongan mengenai penggunaan media pembelajaran berbasis teknologi informasi dan komunikasi, diketahui bahwa sebagian besar sekolah/madrasah memiliki 
media berbasis ICT dan sebagian besar guru menyatakan kadang-kadang menggunakan media yang dimiliki, selebihnya menyatakan tidak dan sering.

Realitas kompetensi guru PAI di kota Pekalongan tersebut akan mempengaruhi terhadap pencapaian tujuan penyelenggaraan pendidikan pada sekolah/madrasah di kota Pekalongan. Hal ini penting karena kompetensi guru memegang peranan yang dominan bagi pencapaian tujuan pendidikan. Oleh karena itu, guru seharusnya memilki kompetensi yang memadai untuk mengembangkan potensi peserta didik secara utuh dan oiptimal. Dinyatakan dengan tegas dalam UU Nomor 14 tahun 2005 tentang Guru dan Dosen, bahwa guru adalah pendidik profesional dengan tugas utama mendidik, mengajar, membimbing, mengarahkan, melatih, menilai, dan mengevaluasi peserta didik pada pendidikan anak usia dini jalur pendidikan formal, pendidikan dasar, dan pendidikan menengah. Guru harus memiliki beberapa kompetensi, antara lain: (1) kompetensi pedagogik, (2) kompetensi kepribadian, kompetensi sosial, dan kompetensi profesional. Sedangkan, menurut Permenag Nomor 16 Tahun 2010 pasal 10, guru Pendidikan Agama Islam harus memiliki kompetensi pedagogik, kepribadian, sosial, profesional, dan kepemimpinan.

Malahan, dalam Peraturan Menteri Pendidikan Nasional Nomor 16 Tahun 2007 tentang Standar Kualifikasi Akademik dan Kompetensi Guru dijelaskan bahwa guru harus memanfaatkan teknologi informasi dan komunikasi untuk kepentingan pembelajaran. Selain itu, guru juga harus memanfaatkan teknologi informasi dan komunikasi untuk berkomunikasi dan mengembangkan diri. Walhasil, pada dasarnya pemanfaatan media pembelajaran dalam proses pembelajaran adalah sangat penting dan menunjang ketercapaian tujuan pembelajaran secara optimal. Peran media dalam proses pembelajaran dapat membantu siswa mempermudah pemahaman tentang materi yang diajarkan. Pemanfaatan ilmu teknologi dan informasi sebagai media yang mendukung proses pembelajaran serta memudahkan guru dalam menyampaikan dan memberikan pengertian secara konkrit kepada siswa terhadap materi yang abstrak untuk diajarkan. Selain itu, media yang digunakan guru juga dapat meningkatkan motivasi belajar dan menarik perhatian siswa.

Merujuk permasalahan dan uraian di atas, dilakukan penelitian dengan judul "Pemetaan Kualifikasi, Persepsi, Dan Kompetensi Guru PAI SMP/MTs Se-Kota Pekalongan dalam Pemanfaatan Media Pembelajaran Berbasis Teknologi Informasi dan Komunikasi (TIK)". Penelitian ini sengaja peneleti lakukan pada guru PAI SMP/MTs seKota Pekalongan dengan alasan, pertama, untuk tingkat SMP/MTs Kota Pekalongan ratarata sudah memiliki media berbasis teknologi informasi dan komunikasi (TIK) dan sebagian besar guru PAI SMP/MTs sudah memiliki laptop sendiri. Penelitian ini juga dimaksudkan untuk mengungkap proses perencanaan, produksi, pemanfaatan, dan pengelolaan media pembelajaran berbasis TIk oleh guru. Sebaliknya, akan diungkap juga penyebab keterbatasan guru PAI dalam membuat atau memanfaatkan media pembelajaran berbasis TIK. Dengan demikian, hasil penelitian ini diharapkan menjadi sumbangsih STAIN Pekalongan sebagai perguruan tinggi berbasis riset menuju kampus rahmatal lil 'alamin dengan menghasilkan penelitian yang dapat digunakan sebagai referensi atau bahan untuk peningkatan profesionalisme guru PAI di Kota Pekalongan.

\section{RUMUSAN MASALAH}

Berdasarkan latar belakang masalah yang telah dijelaskan, maka dalam penelitian ini dapat dirumuskan permasalahan, antara lain: 1) Bagaimanakah kualifikasi Akademik Guru PAI SMP/MTs Se-Kota Pekalongan?; 2) Bagaimanakah persepsi Guru PAI SMP/MTs Se-Kota Pekalongan terhadap pemanfaatan media pembelajaran berbasis TIK?; 3) Bagaimanakah kompetensi Guru PAI SMP/MTs Se-Kota Pekalongan dalam Pemanfaatan media berbasis TIK baik dalam merancang, memproduksi dan memanfaatkan media pembelajaran berbasis TIK?; dan 4) Bagaimakah faktor pendukung 
dan penghambat Guru PAI SMP/MTs Se-Kota Pekalongan dalam memanfaatkan media pembelajaran berbasis TIK?

\section{LANDASAN TEORI}

\subsection{Kompetensi Guru}

Menurut Mulyasa (2009:26) kompetensi adalah perpaduan dari pengetahuan, keterampilan, nilai dan sikap yang direfleksikan dalam kebiasaan berfikir dan bertindak. Sedangkan menurut Muhaimin (2004:151), kompetensi adalah seperangkat tindakan intelegen penuh tanggung jawab yang harus dimiliki seseorang sebagai syarat untuk dianggap mampu melaksanakan tugas-tugas dalam bidang pekerjaan tertentu. Dalam Peraturan Pemerintahan Republik Indonesia Nomor 74 Tahun 2008 tentang Guru, dijelaskan bahwa: "kompetensi adalah seperangkat pengetahuan, keterampilan, dan perilaku yang harus dimiliki, dihayati, dan dikuasai oleh guru atau dosen dalam melaksanakan tugas keprofesionalan”.

Berdasarkan beberapa pendapat tersebut dapat disimpulkan bahwa pengertian kompetensi guru adalah pengetahuan, keterampilan dan kemampuan yang dikuasai oleh seseorang yang telah menjadi bagian dari dalam diri guru, sehingga ia dapat melakukan perilaku kognitif, afektif dan psikomotorik dengan sebaik-baiknya.

\subsection{Standar Kompetensi Guru dalam Memanfaatkan Media Pembelajaran}

Menurut Charles dalam Mulyasa (2009:25), mengemukakan bahwa: competency as rational performance which satisfactorily meets the objective for a desired condition (kompetensi merupakan perilaku yang rasional untuk mencapai tujuan yang dipersyaratkan sesuai dengan kondisi yang diharapkan).

Dalam Peraturan Pemerintahan Republik Indonesia Nomor 74 Tahun 2008 tentang guru disebutkan ada beberapa kompetensi yang harus dikuasai guru, antara lain: 1) kompetensi pedagogik, merupakan kemampuan guru dalam pengelolaan pembelajaran peserta didik. 2) kompetensi kepribadian, merupakan seperangkat sikap yang terdapat dalakm pribadi guru, 3) kompetensi sosial, merupakan kemampuan guru sebagai bagian dari masyarakat, dan 4) kompetensi profesional, merupakan kemampuan Guru dalam menguasai pengetahuan bidang ilmu pengetahuan, teknologi, atau seni dan budaya yang diampunya.

Selanjutnya, dalam Permendiknas Nomor 16 Tahun 2007 mengenai Standar Kualifikasi Akademik dan Kompetensi Guru diterangkan bahwa standar guru memuat di antaranya: kompetensi pedagogik, kepribadian, profesional dan sosial yang terintegrasi dalam kinerja guru. Dalam daftar kompetensi tersebut, dapat dikatakan bahwa salah satu kewajiban semua guru adalah memanfaatkan TIK, dan pelaksanaannya dikategorikan dalam dua kelompok, yaitu: (1) memanfaatkan TIK untuk kepentingan pengelolaan pembelajaran (kompetensi pedagogik), dan (2) memanfaatkan TIK untuk berkomunikasi dan mengembangkan keprofesian berkelanjutan (kompetensi profesional).

\subsection{Persepsi Guru PAI}

Persepsi merupakan suatu proses pengorganisasian, penginterpretasian terhadap stimulus yang diterima oleh organisme atau individu sehingga menjadi sesuatu yang berarti, dan merupakan aktivitas yang terintegrasi dalam diri individu (Walgito, 2004:70). Berdasarkan pendapat tersebut dapat dijabarkan bahwa persepsi merupakan suatu proses yang dimulai dari pengamatan hingga terbentuk tanggapan yang terjadi dalam diri individu sehingga individu sadar akan segala sesuatu dalam lingkungannya melalui indera-indera yang dimilikinya, kemudian teraktualkan dalam bentuk sikap tindakan.

Persepsi dalam hal ini adalah cara pandang guru PAI terhadap pemanfaatan media berbasis TIK. Apakah guru memiliki persepsi yang baik/positif ataukah 
sebaliknya, sehingga dengan persepsi inilah yang menjadi salah satu faktor penentu keberhasilan guru dalam mendesain pembelajan yang berbasis TIK.

\subsection{Pemanfaatan Media Pembelajaran Berbasis TIK}

Menurut Puskur Diknas Indonesia, Teknologi Informasi dan Komunikasi (TIK) mencakup dua aspek, yaitu Teknologi Informasi dan Teknologi Komunikasi. Teknologi informasi adalah meliputi segala hal yang berkaitan dengan proses, penggunaan sebagai alat bantu, manipulasi, dan pengelolaan informasi. Teknologi Komunikasi adalah segala hal yang berkaitan dengan penggunaan alat bantu untuk memproses dan mentransfer data dari perangkat yang satu ke lainnya. Dari dua pengertian tersebut dapat disimpulkan bahwa Teknologi Informasi dan Teknologi Komunikasi adalah suatu padanan yang tidak terpisahkan yang mengandung pengertian luas tentang segala kegiatan yang terkait dengan pemrosesan, manipulasi, pengelolaan, dan transfer/pemindahan informasi antar media.

Pemanfaatan teknologi informasi dalam bidang pendidikan sudah merupakan suatu keharusan untuk memfasilitasi dan mempermudah proses pembelajaran, termasuk pembelajaran PAI, seperti menggunakan komputer atau notebook/netbook, liquid crystal display (LCD), interconnection-networking (internet), Compact Disk (CD), flasdisk, dimana pemanfaatannya tersebut dapat membantu proses kegiatan belajar mengajar.

Berikut ini merupakan beberapa contoh media pembelajaran berbasis TIK, antara lain: 1) Powerpoint, 2) Internet, 3) Compact Disk (CD) pembelajaran, 4) Video pembelajaran, 5) Buku Elektronik, 6) Electronic Learning (E-learning).

\subsection{Generasi $Z$}

Dalam teori generasi (Generation Theory) yang dikemukakan Graeme Codrington \& Sue Grant-Marshall, Penguin, (2004) dibedakan 5 generasi manusia berdasarkan tahun kelahirannya, yaitu: (1) Generasi Baby Boomer, lahir 1946-1964; (2) Generasi X, lahir 1965-1980; (3) Generasi Y, lahir 1981-1994, sering disebut generasi millennial; (4) Generasi Z, lahir 1995-2010 (disebut juga iGeneration, GenerasiNet, Generasi Internet). DAN (5) Generasi Alpha, lahir 2011-2025. Kelima generasi tersebut memiliki perbedaan pertumbuhkembangan kepribadian .

Generasi Z (lahir tahun 1995-2010) Disebut juga iGeneration, generasi net atau generasi internet. Generasi Z memiliki karakteristik yang berbeda dengan generasigenerasi sebelumnya, berikut ini karakteristik Generasi Z, anatara lain: 1). Fasih Teknologi , tech-savvy, web-savvy, appfriendly generation. Mereka adalah "generasi digital" yang mahir dan gandrung akan teknologi informasi dan berbagai aplikasi komputer. Mereka dapat mengakses berbagai informasi yang mereka butuhkan secara mudah dan cepat, baik untuk kepentingan pendidikan maupun kepentingan hidup kesehariannya; 2). Sosial. Mereka sangat intens berinteraksi melalui media sosial dengan semua kalangan. Mereka sangat intens berkomunikasi dan berinteraksi dengan semua kalangan, khususnya dengan teman sebaya melalui berbagai situs jejaring, seperti: FaceBook, twitter, atau melalui SMS. Melalui media ini, mereka bisa mengekspresikan apa yang dirasakan dan dipikirkannya secara spontan; 3). Ekspresif. Mereka cenderung toleran dengan perbedaan kultur dan sangat peduli dengan lingkungan; 4). Multitasking. Mereka terbiasa dengan berbagai aktivitas dalam satu waktu yang bersamaan. Mereka bisa membaca, berbicara, menonton, atau mendengarkan musik dalam waktu yang bersamaan. Mereka menginginkan segala sesuatunya dapat dilakukan dan berjalan serba cepat. Mereka tidak menginginkan hal-hal yang bertele-tele dan berbelitbelit; 5). Cepat berpindah dari satu pemikiran/pekerjaan ke pemikiran/pekerjaan lain (fast switcher); dan 6). Senang berbagi (Syamsuri, 2018:5-6). 


\section{METODE PENELITIAN}

Penelitian ini menggunakan metode deskriptif dengan pendekatan kualitatif dan kuantitatif. Teknik Pengambiulan sampelnya dengan teknik purposive sampling. Sampel yang diambil sejumlah 44 guru-guru PAI di SMP/MTs se-Kota Pekalongan. Teknik pengumpulan data yang digunakan, di antaranya: kuesioner, wawancara, dan dokumentasi. Dalam penelitian ini karena menggunakan mixed method maka analisis datanya terbagi menjadi dua, yaitu analisis data deskriptif kualitatif dan analisis data deskriptif kuantitatif. Analisis data kualitattif ditempuh melalui tiga langkah, yaitu: reduksi data, display atau sajian data dan verifikasi atau penyimpulan data, sedangkan analisis data kuantitatif dengan teknik persentase.

\section{HASIL PENELITIAN DAN PEMBAHASAN}

\subsection{Hasil Penelitian}

\subsubsection{Hasil Analisis Pemetaan Kualifikasi Guru SMP/MTs se-kota pekalongan}

Berdasarkan hasil wawancara terstruktur yang dilakukan, diperoleh hasil bahwa semua guru PAI di SMP/MTs se kota pekalongan dalam hal kualifikasi pendidikan sudah memenuhi persyaratan perundang-undangan yang berlaku, yakni mengenai standar pendidik yang tercantum dalam Permendiknas Nomor 32 Tahun 2010, yaitu sudah berpendidikan minimal memiliki jenjang pendidikan strata satu atau S-1. Namun ada beberapa dari guru PAI yang kualifikasi pendidikannya belum sesuai diantaranya ada yang berijasah S-1 PGSD dan S-1 Syariah.

Data dari hasil penelusuran 44 guru pada SMP/MTs se Kota pekalongan, kualifikasi pendidikan guru SMP/MTs se kota pekalongan terdiri dari dua kategori yakni: kualifikasi akademik jenjang Strata satu (S-1) dan Pasca sarjana (S-2) serta perolehan sertifikasi guru sebagian sudah dan sebagian yang lain belum memperoleh sertifikasi guru. Data tersebut dapat disajikan dalam tabel sebagai berikut:

Tabel 1 Persentase kualifikasi Guru PAI SMP/MTs Se Kota Pekalongan

\begin{tabular}{|c|c|c|}
\hline Aspek & Jumlah & $\%$ \\
\hline \multicolumn{3}{|l|}{ Pengalaman Mengajar } \\
\hline$<10$ tahun & 7 & $16 \%$ \\
\hline 11-20 tahun & 13 & $30 \%$ \\
\hline$>20$ tahun & 14 & $32 \%$ \\
\hline Tidak menyebutkan & 10 & $23 \%$ \\
\hline Total & 44 & $100 \%$ \\
\hline \multicolumn{3}{|l|}{ Kualifikasi Akademik } \\
\hline S-1 & 33 & $75 \%$ \\
\hline S-2 & 3 & $7 \%$ \\
\hline Tidak menyebutkan & 8 & $18 \%$ \\
\hline Total & 44 & $100 \%$ \\
\hline \multicolumn{3}{|l|}{ Status Sertifikasi Guru } \\
\hline Sudah bersertifikasi Guru & 26 & $59 \%$ \\
\hline Belum Bersertifikasi Guru & 10 & $23 \%$ \\
\hline Tidak menyebutkan & 8 & $18 \%$ \\
\hline Total & 44 & $100 \%$ \\
\hline
\end{tabular}

Dari Tabel 1 di atas, diketahui bahwa pengalaman mengajar guru hasilnya ternyata cukup bervasiasi mulai kurang dari 10 tahun hingga lebih dari 20 tahun. Secara rinci diperoleh data sebanyak 7 orang $(26 \%)$ pengalaman mengajar kurang dari 10 tahun, 13 orang (30\%) pengalaman mengajar antara 11 tahun s.d 20 tahun dan 14 orang (32\%) pengalaman mengajar sudah lebih dari 20 tahun, selebihnya 10 orang $(23 \%)$ tidak menyebutkan berapa lama pengelaman mengajar mereka. 
Selanjutnya, dari Tabel 1 di atas juga dapat disimpulkan bahwa standar kualifikasi akademik untuk guru-guru SMP/MTs se-kota pekalongan sudah bagus, karena hampir semua sudah berijasah S1 sebanyak 33 guru atau $75 \%$ bahkan ada yang sudah lebih dari itu, 3 orang guru atau $7 \%$ sudah lulus pasca sarjana (S2), selebihnya tidak menyebutkan kualifikasi pendidikan mereka sebanyak 8 guru atau $18 \%$. Namun peneliti yakin walaupun ada $18 \%$ tidak menyebutkan, mereka dapat dipastikan sudah berijasah S-1 karena untuk syarat melamar ke jenjang SMP/MTs sekarang setidak-tidaknya harus sudah lulus S-1.

Kemudian, dari Tabel 1 di atas dapat diketahui bahwa data terkait status sertifikasi guru, sebanyak 26 orang (59\%) guru SMP/MTs se kota pekalongan sudah mendapatkan sertifikasi guru, dan 10 orang (23\%) belum bersertifikasi, selebihnya sejumlah 8 orang (18\%) tidak menyebutkan apakah yang bersangkutan sudah mendapatkan sertifikasi guru ataukah belum.

Sementara itu, apabila dilihat dari data variasi kualifikasi akademik guru PAI SMP/MTs se-Kota Pekalongan yang berijasah S-1, maka diketahui bahwa dari $75 \%$ atau 33 guru yang berijasah S1, ada sebanyak 13 orang guru $(39,4$ \%) yang dari S.1 PAI, 2 orang $(6,1 \%)$ dari S.1 Syariah, dan 1 orang (3\%) berijasah S.1 PG.SD dan sisanya 17 orang $(51,5 \%)$ tidak menyebutkan S.1 dari prodi mana. Dengan demikian, tidak seluruhnya guru PAI SMP/MTs se-Kota Pekalongan berijazah S-1 PAI padahal persyaratan guru PAI adalah berkualifikasi S-1 PAI.

\subsubsection{Hasil Analisis Persepsi Guru PAI SMP/MTs se-Kota Pekalongan terhadap Pemanfaatan Media Pembelajaran Berbasis Teknologi Informasi dan Komunikasi (TIK)}

Hasil analisis statistik deskriptif terkait persepsi guru SMP/MTs se-Kota Pekalongan terhadap pemanfaatan media pembelajaran berbasis teknologi informasi dan komunikasi (TIK) disajikan sebagai berikut:

Tabel 2 Distribusi Persepsi Guru SMP/MTs se-kota pekalongan Terhadap Pemanfaatan Media Pembelajaran Berbasis Teknologi Informasi dan Komunikasi

\begin{tabular}{c|c|c|c}
\hline Interval & Kategori & Frekuensi & Persentase \\
\hline $20 \leq \mathrm{X}<25$ & Baik & 37 & $84 \%$ \\
\hline $15 \leq \mathrm{X}<20$ & Cukup Baik & 7 & $16 \%$ \\
\hline $10 \leq \mathrm{X}<15$ & Kurang Baik & 0 & $0 \%$ \\
\hline $5 \leq \mathrm{X}<10$ & Tidak Baik & 0 & $0 \%$ \\
\hline
\end{tabular}

Berdasarkan Tabel 2 di atas, dapat diketahui bahwa dari sampel 44 guru SMP/MTs se-Kota Pekalongan, terdapat 37 guru (84\%) memiliki kategori kecenderungan/persepsi baik terhadap pemanfaatan media berbasis TIK, dan 7 guru (16\%) memiliki kategori kecenderungan/persepsi cukup baik. Dengan demikian, dapat disimpulkan bahwa persepsi guru tentang pemanfaatan media berbasis TIK bagi guru SMP/MTs se-Kota Pekalongan baik atau positif.

\subsubsection{Hasil Analisis Kompetensi Guru PAI SMP/MTs se-Kota Pekalongan dalam Pemanfaatan Media Pembelajaran Berbasis Teknologi Informasi dan Komunikasi (TIK)}

Analisis Kompetensi Guru SMP/MTs se-Kota Pekalongan dalam Pemanfaatan Media Pembelajaran Berbasis Teknologi Informasi dan Komunikasi (TIK) dibagi menjadi 3 (tiga) aspek yakni: 1) Kompetensi guru dalam merancang media pembelajaran berbasis TIK; 2) Kompetensi guru dalam memproduksi media pembelajaran berbasis TIK; dan 3) Kompetensi guru dalam memanfaatkan media pembelajaran berbasis TIK. 
Analisis pada masing-masing aspek tersebut secara lebih detail dapat dipaparkan sebagai berikut:

\subsubsection{Kompetensi Guru PAI SMP/MTs Se-Kota Pekalongan dalam Merancang Media Pembelajaran Berbasis TIK}

Analisis pada aspek ini didapatkan dari instrumen/angket yang diberikan kepada guru SMP/MTs se-Kota Pekalongan dengan sampel sebanyak 44 guru di berbagai sekolah baik SMP maupun MTs. Kegiatan merangcang media pembelajaran berbasis TIK dikelompokkan kedalam 6 (enam) indikator, yaitu:

1) Menganalisis kebutuhan media berdasarkan standard kompetensi

2) Menganalisis kebutuhan media berdasarkan karakteristik siswa

3) Menganalisis kebutuhan media berdasarkan sumber daya yang ada (guru, fasilitas, anggaran)

4) Menganalisis kebutuhan media berdasarkan materi yang akan diajarkan

5) Menganalisis kebutuhan media berdasarkan metode yang digunakan

6) Merancang media yang akan dimanfaatkan

Distribusi kompetensi Guru PAI SMP/MTs Se-Kota Pekalongan dalam merancang media pembelajaran berbasis TIK adalah sebagai berikut.

Tabel 3 Distribusi Kompetensi Guru PAI SMP/MTs Se-Kota Pekalongan dalam merancang media pembelajaran berbasis TIK

\begin{tabular}{c|c|c|c}
\hline Interval & Kategori & Frekuensi & Persentase \\
\hline $40 \leq \mathrm{X}<50$ & Baik & 21 & $47,7 \%$ \\
\hline $30 \leq \mathrm{X}<40$ & Cukup Baik & 22 & $50,0 \%$ \\
\hline $20 \leq \mathrm{X}<30$ & Kurang Baik & 1 & $2,3 \%$ \\
\hline $10 \leq \mathrm{X}<20$ & Tidak Baik & 0 & $0 \%$ \\
\hline
\end{tabular}

Berdasarkan Tabel 3 di atas, dapat diketahui bahwa dari sampel 44 guru SMP/MTs se-Kota Pekalongan, terdapat 21 orang guru $(47,7 \%)$ memiliki kategori baik kompetensinya dalam merancang media pembelajaran berbasis TIK, 22 orang guru (50\%) memiliki kategori cukup baik, 1 orang guru $(2,3 \%)$ memiliki kategori kurang baik dan tidak ada guru yang memiliki kategori tidak baik. Sehingga dapat disimpulkan bahwa, kompetensi guru dalam merancang media pembelajaran berbasis TIK bagi guru SMP/MTs se-Kota Pekalongan dalam kategori cukup baik.

Jika dianalisis secara lebih rinci dari 6 indikator yang termasuk dalam kegiatan merancang media pembelajaran berbasis TIK, diperoleh hasil sebagai berikut:

Tabel 4 Hasil Analisis Indikator Kompetensi Guru PAI SMP/MTs Se-Kota Pekalongan dalam merancang media pembelajaran berbasis TIK

\begin{tabular}{l|l|l|l}
\hline Indikator & $\begin{array}{l}\text { Jumlah Item } \\
\text { Pertanyaan }\end{array}$ & Skor & Kategori \\
\hline $\begin{array}{l}\text { Menganalisis kebutuhan media } \\
\text { berdasarkan standard kompetensi }\end{array}$ & 2 & 7,8 & Cukup Baik \\
\hline $\begin{array}{l}\text { Menganalisis kebutuhan media } \\
\text { berdasarkan karakteristik siswa }\end{array}$ & 1 & 3,8 & Cukup Baik \\
\hline $\begin{array}{l}\text { Menganalisis kebutuhan media } \\
\text { berdasarkan sumber daya yang ada } \\
\text { (guru, fasilitas, anggaran) }\end{array}$ & 1 & 3,9 & Cukup Baik \\
\hline $\begin{array}{l}\text { Menganalisis kebutuhan media } \\
\text { berdasarkan materi yang akan diajarkan }\end{array}$ & 2 & 8,0 & Cukup Baik \\
\hline
\end{tabular}




\begin{tabular}{l|l|l|l}
\hline $\begin{array}{l}\text { Menganalisis kebutuhan media } \\
\text { berdasarkan metode yang digunakan }\end{array}$ & 1 & 4,3 & Baik \\
\hline $\begin{array}{l}\text { Merancang media yang akan } \\
\text { dimanfaatkan }\end{array}$ & 3 & 11,2 & Cukup Baik \\
\hline Total Skor & 10 & 39,0 & Cukup Baik \\
\hline
\end{tabular}

Dari Tabel 4 di atas, diketahui bahwa kemampuan guru dalam merancang media pembelaran berbasis TIK diperoleh total skor 39,0 termasuk dalam kategori cukup baik. Perolehan skor cukup baik ratarata tersebar pada 5 indikator dalam proses merancang media, mulai dalam menganalisis kebutuhan media berdasarkan standard kompetensi mata pelajaran, berdasarkan karakteristik siswa, berdasarkan sumber daya yang ada (guru, fasilitas, anggaran), berdasarkan materi yang akan diajarkan hingga proses merancang media yang akan dimanfaatkan. Sedangkan dalam menganalisis kebutuhan media berdasarkan metode yang digunakan terhitung dalam kategori Baik.

\subsubsection{Kompetensi Guru PAI SMP/MTs Se-Kota Pekalongan dalam Memproduksi Media Pembelajaran Berbasis TIK}

Analisa Kompetensi Guru PAI SMP/MTs Se-Kota Pekalongan dalam memproduksi media pembelajaran berbasis TIK dikelompokkan ke dalam 2 diskriptor, yaitu: membuat media yang akan dimanfaatkan dan mengembangkan media yang sudah ada.

Dari 2 deskriptor tersebut kemudian diturunkan menjadi 10 item pertanyaan yang dianalisis dengan teknik statistik deskriptif dan disajikan sebagai berikut:

Tabel 5 Distribusi Kompetensi Guru PAI SMP/MTs Se-Kota Pekalongan dalam memproduksi media pembelajaran berbasis TIK

\begin{tabular}{c|c|c|c}
\hline Interval & Kategori & Frekuensi & Persentase \\
\hline $40 \leq \mathrm{X}<50$ & Baik & 8 & $18,2 \%$ \\
\hline $30 \leq \mathrm{X}<40$ & Cukup Baik & 23 & $52,3 \%$ \\
\hline $20 \leq \mathrm{X}<30$ & Kurang Baik & 12 & $27,3 \%$ \\
\hline $10 \leq \mathrm{X}<20$ & Tidak Baik & 1 & $2,3 \%$ \\
\hline
\end{tabular}

Berdasarkan Tabel 5 di atas, dapat diketahui bahwa dari sampel 44 guru SMP/MTs se-Kota Pekalongan, terdapat 8 orang guru $(18,2 \%)$ memiliki kategori baik kompetensinya dalam memproduksi media pembelajaran berbasis TIK, 23 orang guru $(52,3 \%)$ memiliki kategori cukup baik, 12 orang guru $(27,3 \%)$ memiliki kategori kurang baik dan 1 orang guru $(2,3 \%)$ memiliki kategori tidak baik. Sehingga dapat disimpulkan bahwa, kompetensi guru dalam memproduksi media pembelajaran berbasis TIK bagi guru SMP/MTs se-Kota Pekalongan dalam kategori cukup baik

Jika dianalisis dari 2 deskriptor kegiatan memproduksi media pembelajaran berbasis TIK, diperoleh hasil sebagai berikut:

Tabel 6 Hasil Analisis Indikator Kompetensi Guru PAI SMP/MTs Se-Kota

Pekalongan dalam memproduksi media pembelajaran berbasis TIK

\begin{tabular}{l|c|c|c}
\hline Indikator & $\begin{array}{l}\text { Jumlah Item } \\
\text { Pertanyaan }\end{array}$ & Skor & Kategori \\
\hline Membuat media yang akan dimanfaatkan & 7 & 23,7 & Cukup Baik \\
\hline Mengembangkan media yang sudah ada & 3 & 9,8 & Cukup Baik \\
\hline Skor Total & 10 & 33,5 & Cukup Baik \\
\hline
\end{tabular}

Dari hasil analisis di atas, diketahui bahwa kemampuan guru dalam memproduksi media pembelaran berbasis TIK diperoleh skor 
total 33,5 termasuk dalam kategori cukup baik. Jika dianalisis pada skor masing-masing diskriptor diperoleh hasil yang seimbang baik dalam aspek membuat media dan dalam mengembangkan medi, dua-duanya diperoleh hasil cukup baik.

\subsubsection{Kompetensi Guru PAI SMP/MTs Se-Kota Pekalongan dalam Menggunakan Media Pembelajaran Berbasis TIK}

Kompetensi Guru SMP/MTs se-Kota Pekalongan dalam Pemanfaatan Media Pembelajaran Berbasis Teknologi Informasi dan Komunikasi (TIK) yang ketiga dilihat dari aspek keahliannya menggunakan media pembelajaran berbasis TIK. Pada Aspek ini diturunkan menjadi 3 (Tiga) diskriptor yaitu: 1) Memanfaatkan TIK sebagai media pembelajaran; 2) Memanfaatkan TIK sebagai sumber belajar dan mendukung proses pembelajaran; dan 3) Mengoperasikan media pembelajaran berbasis TIK

Berikut adalah tabel distribusi Kompetensi Guru PAI SMP/MTs Se-Kota Pekalongan dalam menggunakan media pembelajaran berbasis TIK.

Tabel 7 Tabel Distribusi Kompetensi Guru PAI SMP/MTs Se-Kota Pekalongan dalam menggunakan media pembelajaran berbasis TIK

\begin{tabular}{c|c|c|c}
\hline Interval & Kategori & Frekuensi & Persentase \\
\hline $60 \leq \mathrm{X}<75$ & Baik & 2 & $4,5 \%$ \\
\hline $45 \leq \mathrm{X}<60$ & Cukup Baik & 28 & $63,6 \%$ \\
\hline $30 \leq \mathrm{X}<45$ & Kurang Baik & 13 & $29,5 \%$ \\
\hline $15 \leq \mathrm{X}<30$ & Tidak Baik & 1 & $2,3 \%$ \\
\hline
\end{tabular}

Berdasarkan Tabel 7 di atas, dapat diketahui bahwa dari sampel 44 guru SMP/MTs se-Kota Pekalongan, terdapat 2 orang guru $(4,5 \%)$ memiliki kategori baik kompetensinya dalam menggunakan media pembelajaran berbasis TIK, 28 orang guru $(63,6 \%)$ memiliki kategori cukup baik, 13 orang guru (29,5\%) memiliki kategori kurang baik dan 1 orang guru $(2,3 \%)$ memiliki kategori tidak baik. Sehingga dapat disimpulkan bahwa, kompetensi guru dalam menggunakan media pembelajaran berbasis TIK bagi guru SMP/MTs se-Kota Pekalongan dalam kategori cukup baik

Jika dianalisis dari 3 indikator kegiatan menggunakan media pembelajaran berbasis TIK, diperoleh hasil sebagai berikut:

Tabel 8 Hasil Analisis Indikator Kompetensi Guru PAI SMP/MTs Se-Kota

Pekalongan dalam menggunakan media pembelajaran berbasis TIK

\begin{tabular}{l|l|l|l}
\hline Indikator & $\begin{array}{l}\text { Jumlah Item } \\
\text { Pertanyaan }\end{array}$ & Skor & Kategori \\
\hline $\begin{array}{l}\text { Memanfaatkan TIK sebagai media } \\
\text { pembelajaran }\end{array}$ & 5 & 19,0 & Cukup Baik \\
\hline $\begin{array}{l}\text { Memanfaatkan TIK sebagai sumber } \\
\text { belajar dan mendukung proses } \\
\text { pembelajaran }\end{array}$ & 5 & 12,0 & Kurang Baik \\
\hline $\begin{array}{l}\text { Mengoperasikan media pembelajaran } \\
\text { berbasis TIK }\end{array}$ & 5 & 16,7 & Cukup Baik \\
\hline Skor Total & 15 & 47,7 & Cukup Baik \\
\hline
\end{tabular}

Dari hasil analisis di atas, diketahui bahwa kemampuan guru dalam menggunakan media pembelaran berbasis TIK diperoleh skor total 47,7 termasuk dalam kategori cukup baik. Dari tiga indikator kegiatan menggunakan media pembelaran berbasis TIK diperoleh skor kategori cukup baik pada aspek memanfaatkan TIK sebagai media 
pembelajaran dengan skor 19,0 dan mengoperasikan media pembelajaran berbasis TIK dengan skor 16,7.

Skor paling rendah yakni pada aspek memanfaatkan TIK sebagai sumber belajar dan mendukung proses pembelajaran, diperoleh skor 12,0 termasuk dalam kategori kurang baik. Guru-guru yang bersangkutan merasa bahwa keahlian dan kompetensinya masih kurang sehingga memandang perlu adanya pelatihan khusus untuk menunjang kompetensinya dalam menggunakan media berbasis TIK, diantaranya: 1) menggunakan program powerpoint, 2) memanfaatkan video, gambar dan dll, 3)menggunakan email, 4) menggunakan mailing list dan 5) memanfaatkan weblog.

Dapat disimpulkan dari hasil analisis di atas bahwa kompetensi guru SMP/MTs se-Kota Pekalongan dalam memanfaatkan media berbasis TIK dapat dilihat dari 3 aspek, sebagaimana dalam diagram berikut:

Gambar 1 Kompetensi Guru SMP/Mts se-Kota Pekalongan dalam pemanfaatan media berbasis TIK

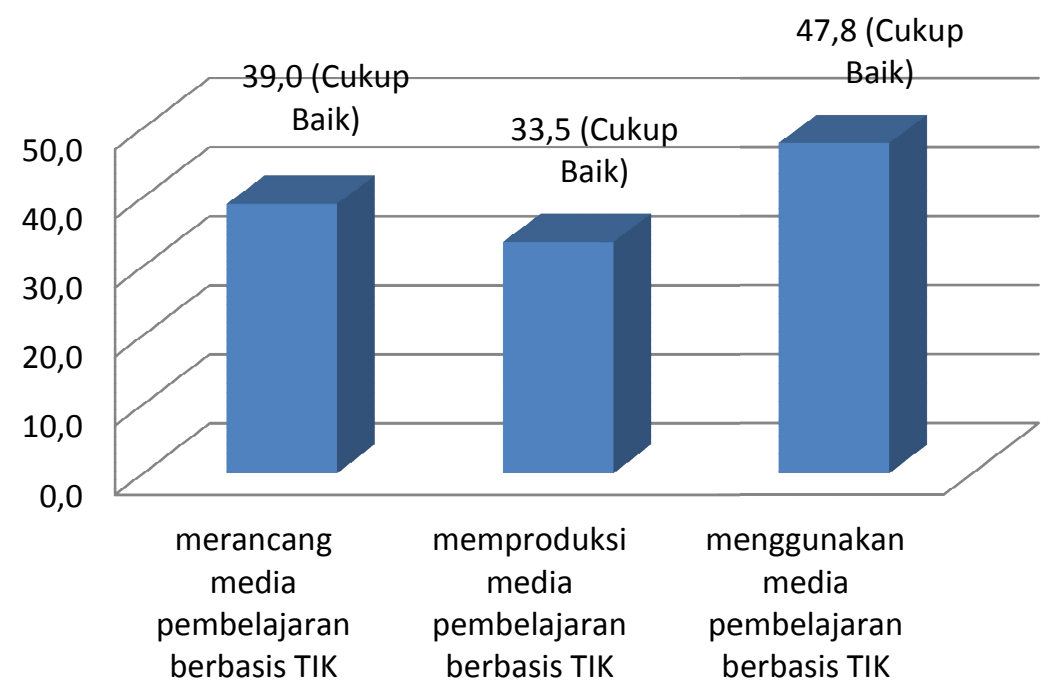

\subsubsection{Faktor pendukung dan penghambat Guru PAI SMP/MTs Se-Kota Pekalongan dalam memanfaatkan media pembelajaran berbasis TIK}

Dari hasil wawancara dengan guru, dapat kami sajikan beberapa faktorfaktor pendukung dan penghambat dalam pemanfaatan media berbasis TIK, sebagai berikut:

\subsubsection{Faktor Pendukung Guru PAI SMP/MTs Se-Kota Pekalongan} dalam memanfaatkan media pembelajaran berbasis TIK

Berdasarkan hasil penelitian, didapatkan bahwa terdapat beberapa faktor yang dapat mendukung pengembangan penerapan TIK sebagai media interaksi guru dan murid di SMP/MTs se-Kota Pekalongan, antara lain dapat diklasifikasikan sebagai berikut:

1. Sarana dan prasarana berbasis TIK yang tersedia di sekolah.

Menurut pendapat guru-guru SMP/MTs se-Kota Pekalongan, hal ini merupakan syarat utama yang mendorong guru dalam memanfaatkan media pembelajaran berbasis TIK. Diantaranya adalah membutuhkan sarana dan prasarana yang memadai seperti Ruang kelas multimedia yang dilengkapi dengan sarana dan prasarana pendukung kegiatan belajar mengajar (LCD, Proyektor, 
sound speaker dan wifi, dan roll kabel). Oleh karenanya dukungan yang tinggi dari seluruh warga sekolah, termasuk komite sekolah, serta pemerintah daerah untuk mewujudkan ketersediaan media TIK yang memadai di sekolah sangat dibutuhkan.

2. Sumber daya manusia (SDM).

Menurut keterangan beberapa guru, menyatakan bahwa sarana prasarana penting untuk menunjang aktivitas KBM guru yang berbasis TIK, namun juga ada hal yang lebih penting lagi yang bisa mengoptimalkan kualitas pembelajaran yaitu: (1) Adanya kemauan dan keinginan guru untuk memberikan pembelajaran yang lebih baik dan memudahkan pemahaman anak didik, (2) Adanya motivasi dari teman-teman dan guru yang muda (yunior) untuk membuat desain pembelajaran berbasis TIK. Tidak bisa dipungkiri bahwa tuntutan zaman, dengan TIK KBM lebih mudah disampaikan dan yang ke-(3) Adanya niatan yang diberikan Allah SWT (semoga Allah selalu membimbing dalam kebaikan, baik niatan maupun dalam perbuatan).

Di samping, kemauan, niatan dan lingkungan/mitra guru di sekolah yang menunjang namun kompetensi guru dalam merancang, memproduksi dan menggunakan media berbasis TIK juga sangat berperan dalam memaksimalkan pembelajaran berbasis TIK di sekolahnya.

Siswa. Kemampuan siswa yang tanggap teknologi juga ikut berperan besar dalam menunjang suksesnya pemanfaatan media berbasis TIK. Menurut salah satu dari guru yang kami wawancarai berpendapat bahwa: "Perlu kemampuan peserta didik yang cukup baik dalam membrowsing informasi yang dibutuhkan dalam kegiatan KBM ataupun tugas". Jadi siswa dalam hal ini harus memiliki antusiasme yang lebih dan mengetahui perkembangan zaman.

Oleh karena dalam hal SDM ini sangat dibutuhkan tingginya motivasi warga sekolah (guru, siswa, komite dan lain-laian) yang ingin maju dan ingin selalu mengikuti perkembangan IPTEK terutama dalam mendesain pembelajaran berbasis TIK

\subsubsection{Faktor Penghambat Guru PAI SMP/MTs Se-Kota Pekalongan dalam memanfaatkan media pembelajaran berbasis TIK}

Berdasarkan hasil penelitian, dapat diketahui bahwa ada beberapa faktor yang menghambat dalam menerapkan TIK sebagai media interaksi guru dan siswa di sekolah ini, antara lain: (1) Kompetensi guru dalam hal TIK, (2) Keterbatasan sarana dan prasarana, (3) Kemampuan siswa, dan (4) Kecepatan akses internet belum memadai.

Aspek pertama, yang menghambat pemanfaatan media berbasis TIK adalah kompetensi guru dalam hal TIK. Sekitar $32 \%$ dari guruguru PAI SMP/MTs se-Kota pekalongan memiliki pengalaman mengajar lebih dari 20 tahun. Tingkat usia dan kesenioran ini menjadi salah satu faktor penghambatnya. Semakin senior seseorang, semakin mapan usia dan keadaan finansialnya, semakin banyak pula pengangalaman mengajarnya. Seiring dengan kemapanan baik usia maupun finansial ini membuat guru terkadang kekurangan motivasi untuk meningkatkan kompetensinya. Guru cenderung untuk menerima apa yang ada tanpa menginginkan perubahan yang membuatnya lebih repot atau bisa dikatakan sudah berada di zona aman. Sehingga adanya 
perubahan perkembangan zaman yang menuntut guru harus lebih kreatif dan inovatif dalam mendesain pembelajaran bahkan menyiapkan media berbasis TIK dianggap repot, susah bahkan ada yang menyatakan tidak menguasai dan tidak bisa mengoperasikan komputer, ada pula yang mengatakan malas menggunakan.

Hal ini sebagaimana yang disampaikan oleh salah satu guru bahwa: "pengetahuan dalam hal TIK sangat kurang, karena sudah tua sehingga terjadi penurunan daya ingat. Walaupun sudah belajar tetapi sering lupa, sehingga menjadi malas menggunakan, bahkan kadang LCD Mati”.

Dengan demikian, hal yang penting disini adalah guru harus ditingkatkan kesadarannya. Kesadaran kalangan pendidik guru dan calon guru tentang manfaat TIK harus dibuat. Kesadaran ini perlu dibuat supaya guru memiliki motivasi yang kuat untuk selalu mencoba hal baru, termasuk juga dalam menggunakan TIK ini. Sehingga walaupun keterbatasan kemampuan visual diakibatkan menurunnya fungsi penglihatan akibat faktor usia bukan menjadikan halangan lagi. Disini juga melihat perlunya pelatihan pengembangan media berbasis TIK baik ditingkat kota maupun propinsi

Aspek yang kedua, adalah minimnya sarana dan prasarana yang ada. Hampir sebagian besar guru menyatakan sarana dan prasarana yang mendukung belum lengkap dan belum memadai karena tanpa adanya sarana dan prasarana yang mendukung maka penerapan TIK di bidang pendidikan tidak bisa tercapai. Sarana dan prasarana merupakan komponen yang sangat penting yang berfungsi sebagai modal awal dan utama dalam penerapan TIK di bidang pendidikan.

Menurut pernyataan salah satu guru mengungkapkan bahwa: " $D i$ sekolah belum terpenuhinya kebutuhan LCD dan proyektor disemua kelas, baru dua ruang kelas yang terpasang LCD sehingga tidak setiap saat guru bisa mengajar dengan menggunakan pembelajaran berbasis TIK, Minimnya alat alat yang dimiliki tersebut sehingga harus bergantian ketika mau menggunakan LCD”.

Sebagian guru yang lain juga mengungkapkan bahwa: Kurangnya waktu untuk mata pelajaran PAI karena jam pelajaran yang hanya 2 jam pelajaran, sehingga ribet kalau harus menyiapkan LCD, proyektor dan lain lain memakan jam pelaran. Apalagi sarana prasarana kurang (LCD, Proyektor sound speaker dan wifi jumlahnya terbatas) sehingga harus bergantian".

Aspek penghambat ketiga, ada pada kemampuan siswanya. Latar belakang ekonomi siswa yang berada pada golongan menengah ke bawah juga menghambat penerapan TIK. Hal in dikarenakan penerapan TIK ini memerlukan dana yang besar seperti adanya tugas mencari data di internet yang mengharuskan siswa ke warnet, mengeprint makalah/tugas dari gurunya dan lain-lain. Akibatnya kondisi ekonomi pada golongan ini akan menghambat penerapan TIK. Sehingga diperlukan dukungan dana dari berbagai sektor, baik sekolah, keluarga maupun pemerintah.

Kendala lain selain faktor ekonomi juga karena potensi anak yang bervariasi, di beberapa sekolah yang memiliki anak didik belum familiar dengan media TIK membuat pembelajaran terhambat. Menurut pernyataan dari salah satu guru menyatakan bahwa: "murid tidak konek dengan media TIK, tugas-tugas yang berhubungan dengan 
internet membuat anak kesulitan dan merepotkan" karena hanya ada fasilitas wifi di sekolah dan jika tugas itu sifatnya PR, maka anak harus ke warnet. Disamping itu juga disampaiakan guru bahwa: "karena asyiknya pembelajaran berbasis TIK seperti power point, video dan sebagainya, peserta didik keasyikan dan tidak mencatat ringkasan materi ajar".

Penelitian ini menyebutkan bahwa hambatan yang lain atau aspek keempat adalah terbatasnya akses internet. Kecepatan akses internet di sekolah ini tidak memadai untuk dimanfaatkan semua warga sekolah. Padahal untuk mendukung penerapan TIK di sekolah, diperlukan komputer dan akses internet yang memadai di tiap kelas. Sekurangnya komputer dengan akses internet dan LCD proyektor disediakan tiap kelas. Sedangkan untuk komputer tiap kelas bisa diatasi dengan tiap siswa yang membawa laptop atau notebook atau bahkan smartphone termasuk android. Sedangkan akses komputer yang memadai digunakan untuk mencari sumber daya pembelajaran atau untuk mengerjakan tes online. Keadaan ini perlu ada di sekolah supaya TIK bisa diterapkan secara optimal.

\subsection{Hasil Penelitian}

Perkembangan teknologi informasi dan komunikasi yang demikian pesat membawa perubahan pada bergesernya peranan guru sebagai penyampai pesan atau materi pelajaran. Guru tidak lagi berperan sebagai satu-satunya sumber belajar dalam kegiatan pembelajaran. Peserta didik dapat memperoleh informasi dari berbagai media dan sumber belajar seperti dari majalah, modul, siaran radio pembelajaran, televisi edukasi, dan media komputer atau yang lebih dikenal dengan pembelajaran berbasis Teknologi Informasi dan Komunikasi (TIK) atau e-learning.

Hasil penelitian ini menunjukkan bahawa Secara sederhana persyaratan untuk menjadi guru dari segi kualifikasi sudah terpenuhi. Karena guru merupakan sebuah profesi yang dituntut sebuah kualifikasi dan keahlian khusus atau kompetensi khusus. Profesi guru memerlukan sebuah kemampuan intelektual yang diperoleh melalui pendidikan, memiliki pengetahuan secara teoris dan praktis untuk menunjang proses belajar mengajar. Oleh karena untuk menjadi seorang guru minimal serendahrendahnya harus sudah lulus jenjang pendidikan strata satu atau S-1. Namun, kesesuaian kualifikasinya juga harus diperhatikan, sehingga guru PAI yang belum sesuai kualifikasi S-1 PAI diharapkan dapat mengambil program penyesuaian kualifikasi melalui program Dual Mode System (DMS).

Dalam penelitian ini selain penelusuran kualifikasi akademik juga menelusuri berapa lama mengajar guru PAI SMP/MTs se-kota Pekalongan. Hasil penelitian ini, menunjukkan bahwa guru PAI memiliki pengalaman mengajar yang cukup bervasiasi mulai kurang dari 10 tahun hingga lebih dari 20 tahun. Pengalaman mengajar guru juga merupakan sebuah indikator kualitas mengajar guru.

Hasil penelitian ini mengisayaratkan bahwa standar kualifikasi pendidikan saja sebenarnya belumlah cukup untuk dapat mengangkat kualitas pendidikan, kompetensi sosial guru sangat diharapkan dapat memenuhi semua alat, media dan sumber belajar siswa yang dibutuhkan dalam proses belajar siswa. Guru diharapkan dapat menemukan dan mengembangkan kreativitas dan inovasinya dalam proses pembelajaran siswa. Menerapkan pembelajaran dengan berbagai media, alat dan sumber belajar yang bervariasi dan berbasis TIK, membutuhkan sebuah kreativitas dan kesadaran yang tinggi dari masing-masing guru baik itu yang berstatus negeri maupun swasta.

Persepsi guru terkait pemanfaatan media pembelajaran yang berbasis Teknologi Informasi dan Komunikasi (TIK) adalah sebuah unsur penting menunjang 
kualitas pembelajaran itu sendiri. Dari hasil penelitian ini, disimpulkan bahwa persepsi guru tentang pemanfaatan media berbasis TIK bagi guru SMP/MTs se-Kota Pekalongan baik atau positif. Dengan persepsi yang positif terhadap media pembelajaran berbasis TIK peneliti yakin bahwa Guru-guru PAI SMP/MTs se-Kota Pekalongan akan memiliki motovasi yang kuat untuk menyajikan atau mendesain pembelajaran yang kreatif dan inovatif dalam memanfaatkan media yang tersedia, walaupun dengan berbagai keterbatasan yang ada.

Hasil penelitian ini mengungkap bahwa 1) kompetensi guru dalam merancang media pembelajaran berbasis TIK bagi guru SMP/MTs se-Kota Pekalongan dalam kategori cukup baik; 2) Kompetensi guru dalam memproduksi media pembelajaran berbasis TIK bagi guru SMP/MTs se-Kota Pekalongan dalam kategori cukup baik; dan 3) Kompetensi guru dalam menggunakan media pembelajaran berbasis TIK bagi guru SMP/MTs se-Kota Pekalongan dalam kategori cukup baik

Kompetensi Guru PAI SMP/MTs Se-Kota Pekalongan dalam merancang media pembelajaran berbasis TIK merupakan langkah awal seorang guru dalam mengidentifikasi dan mengklasifikasikan media pembelajaran yang sesuai dengan standar kompetensi mata pelajaran, materi ajar dan karakteristik siswa. Sehingga guru dapat merangcang media pembelajaran dan menentukan strategi pembelajaran yang tepat sasaran dan sesuai dengan kebutuhan. Kompetensi guru dalam memanfaatkan media pembelajaran berbasis TIK yang kedua yang harus dikuasai oleh dosen adalah kegiatan memproduksi memproduksi media pembelajaran berbasis TIK

Pemanfaatan media berbasis TIK dalam bidang pendidikan, merupakan respons positif terhadap perkembangan teknologi informasi dan komunikasi pada abad modern. Oleh karena itu, penggunaan media TIK di SMP/MTS se kota Pekalongan dalam menunjang pembelajaran merupakan suatu keharusan, bukan hanya untuk meningkatkan efektifitas dan kualitas pembelajaran, tetapi yang lebih penting adalah untuk meningkatkan penguasaan TIK baik bagi guru maupun siswa. Dalam pembelajaran, media memegang peranan penting dalam mencapai sebuah tujuan belajar. Hubungan komunikasi antara guru dan peserta didik akan lebih baik dan efisien jika menggunakan media.

Hasil penelitian ini menyebut bahwa faktor pendukung Guru PAI SMP/MTs Se-Kota Pekalongan dalam memanfaatkan media pembelajaran berbasis TIK antara lain: Sarana dan prasarana berbasis TIK yang tersedia di sekolah dan Sumber Daya Manusia (SDM) yang meliputi guru dan siswa. Sementara itu, faktor penghambat Guru PAI SMP/MTs Se-Kota Pekalongan dalam memanfaatkan media pembelajaran berbasis TIK, antara lain: (1) Kompetensi guru dalam hal TIK, (2) Keterbatasan sarana dan prasarana, (3) Kemampuan siswa, dan (4) Kecepatan akses internet belum memadai

Urgensi pemanfaatan media berbasis TIK itulah hendaknya mendorong para guru senantiasa aktif, kreatif dalam membuat desain pembelajaran yang berbasis TIK. Namun kendala dilapangan yang sering dikeluhkan guru dalam memanfaatkan media berbasis TIK nampaknya perlu diperhatikan dan bahkan perlu solusi dan tindak lanjut.

\section{SIMPULAN}

Berdasarkan hasil penelitian dan pembahasan di atas disimpulkan bahwa semua guru PAI di SMP/MTs se kota pekalongan sudah memenuhi persyaratan perundangundangan yang berlaku (Permendiknas Nomor 32 Tahun 2010 mengenai standar pendidik). Persepsi Guru SMP/MTs se-kota pekalongan terhadap pemanfaatan media pembelajaran berbasis TIK termasuk kategori kecenderungan/persepsi cukup baik. Kompetensi guru SMP/MTs se-Kota Pekalongan dalam pemanfaatan media pembelajaran 
berbasis teknologi Informasi dan komunikasi (TIK) dalam kategori cukup baik. Faktor pendukung dan penghambat guru PAI SMP/MTs Se-Kota Pekalongan dalam memanfaatkan media pembelajaran berbasis TIK terkait: sarana dan prasarana berbasis TIK yang tersedia di sekolah dan sumber daya manusia (SDM) yang meliputi guru dan siswa. Dengan demikian, pertama yang harus disadari oleh guru PAI setelah memiliki persepsi yang baik terhadap pemanfaatan media pembelajaran berbasis TIK adalah guru harus memiliki keterampilan dahulu dalam mengoperasikan komputer sehingga seyogianya guru harus belajar komputer untuk pembelajaran atau mengikuti kursus/pelatihan komputer yang diadakan oleh pihak terkait, agar media pembelajaran yang digunakan dapat dimanfaatkan sesuai dengan materi ajar, kebutuhan siswa, kondisi lingkungan dan sesuai dengan tujuan yang ingin dicapai.

\section{DAFTAR PUSTAKA}

Budiyono. 2011. Penilaian Hasil Belajar. Surakarta: UNS Press.

Haedari, Amin. 2016. "Sambutan Direktur Pendidikan Agama Islam Kementerian Agama RI pada kegiatan Pengembangan Pembelajaran dan Penilaian Kurikulum PAI Angkatan-1 di Serpong Tangerang Selatan". http://pendis.kemenag.go.id/index.php?a=detilberita \&id=7974\#.Vt0Ezn197IV. Tanggal 6 Maret 2016.

Hamalik, Oemar. 2010. Kurikulum dan Pembelajaran. Jakarta: Rajawali.

Hamdani. 2010. Strategi Belajar Mengajar. Bandung: CV Pustaka Setia.

Hernawan, Asep Herry. 2008. Pengembangan Kurikulum dan Pembelajaran. Jakarta: Universitas Terbuka.

Kusuma, Willy. 2012. "Pemanfaatan Teknologi Informasi dalam Pembelajaran". Dalam http://www.slideshare.net/willykusuma9/pemanfaatan-teknologi-informasi-dalampembelajaran. diakses (21 April 2013)

Miftah, Toha. 2003. Perilaku Organisasi Konsep Dasar dan Aplikasinya. Jakarta: PT Raja Grafindo Persada.

Mulyasa, E. 2009. Standar Kompetensi Guru Dan Sertifikasi Guru. Bandung: PT Remaja Rosdakarya.

Miarso, Yusufhadi. 2009. Menyemai Benih Teknologi Pendidikan 2. Jakarta: Kencana Prenada Media Group

Peraturan Pemerintahan Republik Indonesia Nomor 74 Tahun 2008 tentang Guru.

Permenag Nomor 16 Tahun 2010 tentang Pengelolaan Pendidikan Agama Pada Sekolah.

Riyana, Cepi. 2012. "Pengembangan Model Project Based Learning melalui Aplikasi Computer Assisted Instruction untuk Meningkatkan Hasil Belajar". (Disertasi). Bandung : Sekolah Pasca Sarjana UPI Bandung.

Rusman. 2007. "Implementasi Model Pembelajaran Berbasis Komputer untuk Meningkatkan Kompetensi Siswa pada Mata Pelajaran Matematika di Sekolah Menengah Kejuruan”. Bandung : Program Pascasarjana UPI.

Ridwan. 2009. Skala Pengukuran Variabel-Variabel Penelitian. Bandung: Alfabeta.

Sadiman, Arif. 2010. Media Pendidikan Pengertian, Pengembangan, dan Pemanfaatannya. Jakarta: Raja Grafindo Persada.

Saifudin, Azwar. 2003. Penyusunan Skala Psikologi. (Yogyakarta: Pustaka Pelajar.

Sobur, Alex. 2009. Psikologi Umum. Bandung: CV Pustaka Setia.

Sudjana, Nana. 2009. Media Pengajaran. Bandung: Sinar Baru Algensindo.

Sugihartono, dkk. 2007. Psikologi Pendidikan. Yogyakarta: UNY Press.

Sugiyono. 2011. Metode Penelitian Pendidikan Pendidikan Kuantitatif, Kualitatif, dan R\&D. Bandung: Alfabeta.

Suharman. 2005. Psikologi Kognitif. Surabaya: Srikandi.

Sunaryo. 2004. Psikologi untuk Keperawatan, Jakarta: EGC. 
Surya, Mohammad. 2006. Potensi Tekknologi Informasi dan Komunikasi dalam Peningkatan Mutu Pembelajaran di Kelas.Makalah dalam Seminar "Pemanfaatan Teknologi Informasi dan Komunikasi untuk Pendidikan Jarak Jauh dalam Rangka Peningkatan Mutu Pembelajaran" tanggal 12 Desember 2006 di Pustekom Depdiknas Jakarta.

Susilana, Rudi. 2009. Media pembelajaran. Bandung: CV Wacana Prima.

Syamsuri, Andi Sukri dan Ishaq. 2018. "Tantangan Guru, Generasi Z, dan Pembelajaran Abad 21". http://www.unismuh.ac.id/wp-content/uploads/2018/05/Tantangan-GuruGenerasi-Z-dan-Pembelajaran-Abad-21.pdf. Diakses Tanggal 26 Juli 2018.

Tobroni, Imam. 2015. "Kebijakan Kementerian Agama dalam Peningkatan Mutu Pendidikan Islam". Power Point yang Disampaikan pada sebuah Acara, Pekalongan, 1 September 2015.

Undang-Undang Nomor 20 tahun 2003 tentang Sistem Pendidikan Nasional.

Uno, Hamzah. 2009. Perencanaan Pembelajaran. Jakarta: Bumi Aksara.

UU Nomor 14 tahun 2005 tentang Guru dan Dosen.

Waidi. 2006. The Art of Re-engineering Your Mind for Success. Jakarta: Gramedia.

Walgito, Bimo. 2004. Pengantar Psikologi Umum. Yogyakarta: Penerbit Andi.

Yusmuliadi. 2018. "Peningkatan Kualitas Guru di Era Milenial". https://www.kaskus.co.id/thread/5ac9c7bfded770931e8b456b/peningkatan-kualitasguru-di-era-milenial/. Diakses Tanggal 26 Juli 2018. 